\title{
A Study on Customer Perception of Medical Tourism in Puducherry
}

\section{Shanthi Marie* and Sampad Kumar Swain ${ }^{\dagger}$}

\section{Abstract}

Medical tourism is the latest trend happening in many countries of the world where tourists in need of medical treatments from the developed countries approach the developing countries imparting treatments at par with the quality of their home countries. Among the countries practicing medical tourism, India is occupying one of the top positions with respect to the quality treatments as most of the states have recognized its significance. This study aims at studying the customer perception of medical tourism in the union territory of Puducherry. The units of the study are the international medical tourists who sought medical treatments in the private healthcare hospitals of Puducherry. The methodology used for the study is descriptive, analytical and inferential. Factor Analysis, T-test and ANOVA are the tools utilized for analyzing the primary data. The study reveals that the facilities provided to foreign patients are customer oriented. The satisfaction level of patients regarding the staff interaction, facilities and amenities and treatment are high. But, there is some need of improvement in the case of formalities and tourism part. The efficiency of the doctors, their personal touch, their communication skills, the facilities and amenities of the hospitals contributes to the cutting edge experience by the medical tourists. One important drawback is the lack of

\footnotetext{
* Assistant Professor, Dept. of Commerce and Management, Achariya Arts and Science College, Achariyapuram, Villianur, Puducherry, shanthimariemandjiny@yahoo.co.in

† Reader, Department of Tourism Studies, Pondicherry University, Puducherry, sampadswain@gmail.com;
} 
international accreditation which needs utmost ground work. The study finally suggests strategies for motivating the medical tourists undertaking healthcare treatments in Puducherry.

Keywords: Medical tourism, perception, satisfaction, strategies

\section{Introduction}

Medical tourism is an emerging trend in the tourism industry with the privatization of health care services. Especially it is gaining prominence in developing countries like India. It is different from other conventional forms of tourism as it is not destination tourism but medical health package tourism. It refers to the cost effective private medical care in collaboration with the tourism Industry for the foreign patients so that they could get a good health care package. India has the potential to attract foreign patients due to the high quality treatment, service and no waiting time. Before 1990 India was famous for travelling abroad for medical treatment but during 1990-2000, the medical infrastructure were much more organized and the health care outsourcing started and India was able to attract foreign patients. Other than, this India, with its cultural heritage and scenic beauty has become famous for the medical tourism destination where the patient can mingle illness and healthcare with relation and leisure. Puducherry is found to be one of the places of India where tourists involve themselves in medical tourism. This study aims at analyzing the customer's perception about medical tourism in Puducherry and devises a marketing strategy for promoting Puducherry as a medical tourism destination.

\section{Review of Literature}

The outsourcing of medical services is basically medical tourism, aimed at finding a low cost alternative to the expensive treatments available in the wealthy developed countries like the US, UK and other European countries to developing countries like India and Thailand. There are many reasons that motivate medical tourism, the most relevant reasons are-low cost, waiting lists for availing medical treatments. Apart from this it is acceptable as quality is not 
an issue as qualitative and efficient doctors' fraternity is there to impart quality treatment at par with that of the treatments available in the countries of the patient's origin. It is evident as the British National Health Services are subcontracted to India by the UK government [2] \& [3]. It is owing to this reason that many of the third world country doctors are products of the medical institutes of the US and UK. Many hospitals like Apollo and Fortis have a good record of treating international patients in India. Between the year 2001 and 2004 alone around 60,000 patients have been treated at the Apollo Hospital. McKinsey and Company has revealed in one of its studies that medical tourism is increasing at the rate of $30 \%$ per year in India. Moreover, it is expected that the revenue through medical tourism in India will hike up to about $\$ 20$ billion dollars. The total number of medical tourists has also increased, from 19 million travelers in 2005 to 25.8 million in 2007, which is an annual growth rate of $16.5 \%$ (RNCOS, 2008).

Bies and Zacharia (2007) exposed the benefits, opportunities, costs and risks perceived through their study on outsourcing medical tourism like it is less expensive, no waiting is needed, quick service, reduced stress, US trained doctors, good infrastructural chain of hospitals with medical standards and medical treatment combined with vacation, comprising the benefits. The perceived opportunities like provision of services by subcontractors, elective surgery possibility, procedures not covered by insurance, employers wishing to save money for their employees treatment, reduction in insurance premiums were found as the outcome of their study. Studying the perceived costs, it was found that psychological costs, reluctance on the US insurers in sending their insured abroad for treatments, perceived competition against the American system of health care, patients forced to pay cash for certain medical procedures, question of follow-up treatments and loss of US revenue. Complications, side-effects and post-operative care, malpractice laws liable to lack of court recourses, regulatory impediments, accreditation problem, profit making motives of the private hospitals, US losing hospital business, quest for continuous treatments are reveled to be some of the risks.

Based on the study conducted by KHIDI (Korea Health Industry Development Institute, 2009) as cited in Yu and Ko (2012) it was 
identified that the skills of the medical staff, medical services, facilities and equipment and reasonable cost are some of the main reasons, why the tourists came for obtaining treatment in Korea.

It is found that though research cases have been made by corporate interested in medical tourism and medical tourism associations, proper academic research contributing to further research with respect to consumer behaviour and perception and their experiences are falling short.

\section{Objectives of the Study}

- To analyze the customer perception of medical tourism in Puducherry

- To study the prospects of Puducherry emerging as a medical tourism industry, and

- To develop a medical tourism marketing strategy for Puducherry

\section{Need for the Study}

India has become a hub for medical tourism in South East Asia. It is because many of the states of India have identified the potential of the medical tourism business and taken up this opportunity to materialize on it. Puducherry as such receives a large number of tourists and tourism contributes which comes to nearly $5 \%$ of the gross state domestic product. Owing to the increased tourist flow and the significance of the medical tourism a need is felt to position Puducherry as a medical tourism business center. The same could be possible only if the perception of the foreign tourists and NRI's are taken into consideration since they are the target customers for medical tourism. This would make us aware of the prospects of Puducherry emerging as a medical tourism destination.

\section{Scope of the Study}

The study is confined to the headquarters of Puducherry, erstwhile French colony in India which houses many efficient hospitals and physicians. The study puts up a sincere effort to unveil the various 
aspects of medical tourism and its impacts on Puducherry. Hence, there is immense scope for the development of medical tourism business through this study. Another scope is that this study deals with the efforts to bring into the limelight the importance of medical tourism on the economy of the government. Moreover, it will highlight on the future trends and practices of medical tourism.

\section{Methodology of the Study}

The methodology used in the study is descriptive, analytical and inferential. In descriptive studies, the researcher seeks to measure frequency, preferences or similar data. The universe of this research study is the foreign patients. The sampling unit is Puducherry and the sample size chosen for the study is the 90 foreign patients. Both primary as well as secondary data has been utilized for the study. Primary data was collected through questionnaires, observation of the behaviour of patients, informal interviews, interactions with the hospitals and foreign patients. The instrument utilized for data collection is the questionnaire. The secondary data has been collected through internet, books, newspapers, journals, white papers, industry portals, government agencies, trade associations, monitoring industry news and developments, records and brochures. The tools used for the study are percentage analysis, cross tabulations, factor analysis, T-test and ANOVA.

\section{Hypotheses}

$\mathbf{H}_{0}$ : There is no significant difference in terms of age with the level of satisfaction among the five factors.

$\mathbf{H}_{0}$ : There is no significant difference in terms of gender with the level of satisfaction among the five factors.

\section{Overview of Puducherry}

The Union Territory of Puducherry comprises of the four coastal regions - Puducherry, Karaikal, Mahe, and Yanam. Puducherry and Karaikal are enclaves in the south Arcot and Nagapattinam district 
in Tamil Nadu respectively. Yanam is a small village in the East Godavari District in Andhra Pradesh whereas Mahe is an enclave in Kannur District of Kerala. Puducherry is the headquarters of this Union Territory. The Puducherry region lies in the deltaic channels of the River Gingee and Ponnaiyar. It is also endowed with beautiful beaches, many lakes and ponds. The alluvial soil extensively found in the area indicates that Puducherry is situated in the lagoon. It has been a place of attraction for most of the people of the world especially the Europeans due to its fragrance of the blend of the French and the Tamil culture.

\section{Data Analysis}

Table 1. Demographic Profile

\begin{tabular}{|l|l|l|}
\hline Demographic Profiles & Demographic Variables & Percent \\
\hline \hline Nationality & NRI & $47.8 \%$ \\
\hline & Foreign & $52.2 \%$ \\
\hline \hline Gender & Male & $68.9 \%$ \\
\hline \hline & Female & $31.1 \%$ \\
\hline \hline Age & $25-40$ & $74.4 \%$ \\
\hline \hline & $41-55$ & $16.7 \%$ \\
\hline \hline & $56-70$ & $7.8 \%$ \\
\hline \hline Educational Qualification & $71-85$ & $1.1 \%$ \\
\hline \hline & Below Graduation & $11.0 \%$ \\
\hline \hline & Graduation and Post Graduation & $50.7 \%$ \\
\hline & Professional & $38.3 \%$ \\
\hline
\end{tabular}

The above Table- 1 explains about the demographic profilesnationality, gender, age and educational qualification of the respondents. Among the 90 respondents $47.8 \%$ of them are NonResident Indians and $52.2 \%$ of them are foreigners. In the demographic profile, in the column it can be seen that gender $68.9 \%$ of the respondents are males and $31.1 \%$ of them are females. In the age group column it can be seen that $74.4 \%$ of the respondents belong to the age group 25-40, 16.7\% of the respondents belong to $41-55,7.8 \%$ belong to the age group $56-70$ and $1.1 \%$ of the respondents belong to the age group 71-85. As far as the educational background is concerned $11.0 \%$ are below 
graduation, $50.7 \%$ are graduates and post graduates and $38.3 \%$ are professionals. It is interpreted that the majority of the tourists who come for medical tourism are foreigners. The male tourists wish to travel to Puducherry more for undertaking treatments. The majority of the tourists coming for treatments is in the first age group of 25-40 while the least number of tourist fall in the last age group of 71-85. It shows that the younger the tourists are the more they wish to travel for treatments. The educational background of the tourists shows that the more educated people are get exposed to the outside world other than their countries.

Table 2. Purpose, source and contact

\begin{tabular}{|l|l|l|}
\hline Aspects & Items & Percent \\
\hline \hline Purpose of Visit to Puducherry & Recommended by Doctor & $36(40.0 \%)$ \\
\hline \hline & Self Funded Cure & $12(13.3 \%)$ \\
\hline \hline $\begin{array}{l}\text { Source of Information about } \\
\text { the Hospital }\end{array}$ & Holiday and Cure & $42(46.7 \%)$ \\
\hline \hline & Recommended by the Hospital & $15(16.7 \%)$ \\
\hline \hline & Advertisement & $62(68.9 \%)$ \\
\hline \hline \hline Contact with Hospital & Others & $2(2.2 \%)$ \\
\hline \hline & Doctor in home country & $12(13.3 \%)$ \\
\hline \hline & Relatives & $53(58.9 \%)$ \\
\hline \hline & Hospital in Home Country & $1(1.1 \%)$ \\
\hline & E-Mail & $3(3.3 \%)$ \\
\hline
\end{tabular}

The above Table-2 explains the purpose of their visit to Puducherry, the source of information about the hospitals and the contact with the hospital. Less than half of the tourists came for holiday as well as cure. Almost $70 \%$ of the medical tourists have received information about the hospitals through their friends, and the contact established with the hospitals is through relatives. 
Hence, it is the word of mouth which plays a great influence in selecting Puducherry for medical tourism.

Table 3. Budget for the medical trip

\begin{tabular}{|l|r|}
\hline \multicolumn{1}{|c|}{ Budget } & \multicolumn{1}{c|}{ Percent } \\
\hline Less than US\$1000 & $44(48.9 \%)$ \\
\hline US\$ 1000-2000 & $28(31.1 \%)$ \\
\hline US\$ 2000-3000 & $9(10.0 \%)$ \\
\hline US\$ 3000-4000 & $1(1.1 \%)$ \\
\hline US\$ More than 5000 & $8(8.9 \%)$ \\
\hline
\end{tabular}

It is found from the above Table- 3 that almost $50 \%$ of the tourists wish to spend less than US\$1000. A little more than $25 \%$ of the medical tourists wish to spend between US\$ 1000 to 2000 . It is interpreted that Puducherry suits the budget of the medical tourists.

Table 4. Budget for the trip across type of tourism

\begin{tabular}{|c|c|c|c|c|c|c|c|}
\hline Budget & \multicolumn{6}{|c|}{ Type of tourism } & \\
\hline $\begin{array}{l}\text { for the } \\
\text { trip(US } \\
\$ \text { \$) }\end{array}$ & $\begin{array}{l}\text { Seaside } \\
\text { Holiday }\end{array}$ & Heritage & Spiritual & Wildlife & Shopping & Others & Total \\
\hline 氙 & $\begin{array}{c}5 \\
(11.4 \%)\end{array}$ & $\begin{array}{c}18 \\
(40.9 \%)\end{array}$ & $\begin{array}{c}2 \\
(4.5 \%)\end{array}$ & $\begin{array}{c}8 \\
(18.2 \%)\end{array}$ & $\begin{array}{c}3 \\
(6.8 \%)\end{array}$ & $\begin{array}{c}8 \\
(18.2 \%)\end{array}$ & $44(100 \%)$ \\
\hline छे & $\begin{array}{c}4 \\
(14.3 \%)\end{array}$ & $\begin{array}{c}8 \\
(28.6 \%)\end{array}$ & $1(3.6 \%)$ & $\begin{array}{c}14 \\
(50.0 \%)\end{array}$ & $\begin{array}{c}1 \\
(3.6 \%)\end{array}$ & $0(0 \%)$ & $\begin{array}{c}28 \\
(100 \%)\end{array}$ \\
\hline ठ্ণ & $\begin{array}{c}3 \\
(33.3 \%)\end{array}$ & $\begin{array}{c}4 \\
(44.4 \%)\end{array}$ & $0(.0 \%)$ & $\begin{array}{c}0 \\
(.0 \%)\end{array}$ & $\begin{array}{c}2 \\
(22.2 \%)\end{array}$ & $0(.0 \%)$ & $\begin{array}{c}9 \\
(100.0 \%)\end{array}$ \\
\hline ஓి & $\begin{array}{c}0 \\
(.0 \%)\end{array}$ & $\begin{array}{c}1 \\
(100.0 \%)\end{array}$ & $0(.0 \%)$ & $\begin{array}{c}0 \\
(.0 \%)\end{array}$ & $\begin{array}{c}0 \\
(.0 \%)\end{array}$ & $0(.0 \%)$ & $\begin{array}{c}1 \\
(100.0 \%)\end{array}$ \\
\hline 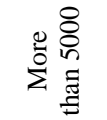 & $\begin{array}{c}1 \\
(12.5 \%)\end{array}$ & $0(.0 \%)$ & $5(62.5 \%)$ & $\begin{array}{c}0 \\
(.0 \%)\end{array}$ & $\begin{array}{c}0 \\
(.0 \%)\end{array}$ & $\begin{array}{c}2 \\
(.25 .0 \%)\end{array}$ & $\begin{array}{c}8 \\
(100.0 \%)\end{array}$ \\
\hline 胥 & $\begin{array}{c}13 \\
(14.4 \%)\end{array}$ & $\begin{array}{c}31 \\
(34.4 \%)\end{array}$ & $\begin{array}{c}8 \\
(8.9 \%)\end{array}$ & $\begin{array}{c}22 \\
(24.4 \%)\end{array}$ & $\begin{array}{c}6 \\
(6.7 \%)\end{array}$ & $\begin{array}{c}10 \\
(11.1 \%)\end{array}$ & $\begin{array}{c}90 \\
(100.0 \%)\end{array}$ \\
\hline
\end{tabular}

The above table- 4 describes that the majority of the medical tourists are also heritage tourists since $34.4 \%$ of the respondents have opted for it and the budget for the same is less than US $\$ 1000$. This shows that Puducherry 
as a medical tourism destination is more affordable and known for its rich heritage among the foreigners.

\section{Factor Analysis}

Table 5. KMO and Bartlett's test

\begin{tabular}{|l|l|l|}
\hline Kaiser-Meyer-Olkin & $\begin{array}{l}\text { Measure of Sampling } \\
\text { Adequacy. }\end{array}$ & .703 \\
\hline Bartlett's Test of Sphericity & Approx. Chi-Square & 1461.567 \\
\cline { 2 - 3 } & Df & 120 \\
\cline { 2 - 3 } & Sig. & .000 \\
\hline
\end{tabular}

It is important to check whether the obtained data is adequate for proceeding with the factor analysis. To confirm this Kaiser-MeyerOlkin test is conducted. It is evident from table-5 that the value .703 is higher than 0.5 and has fulfilled the test of adequacy since the value is significant. The second step in factor analysis is to check for communality between the data and check whether common variances are shared by them through PCA and alpha factoring. From Table- 6 it is clear that all the variables share a communality of 1. It shows that communality exists between the variables since a range of communalities exist between .983 and .557, interpreting that the variables are related to each other.

Table 6. Communalities

\begin{tabular}{|l|c|c|}
\hline & Initial Eigen values & Extraction \\
\hline Pre-visit & 1.000 & .908 \\
Visa & 1.000 & .811 \\
Arrival & 1.000 & .891 \\
Formalities & 1.000 & .711 \\
Accommodation & 1.000 & .815 \\
Food & 1.000 & .814 \\
Medical Cure & 1.000 & .983 \\
Cure & 1.000 & .970 \\
Doctor interaction & 1.000 & .954 \\
Nurses interaction & 1.000 & .973 \\
Technician interaction & 1.000 & .953 \\
Other & 1.000 & .756 \\
Ambience & 1.000 & .786 \\
Excursions & 1.000 & .841 \\
Website information & 1.000 & .557 \\
Overall experience & 1.000 & .611 \\
\hline
\end{tabular}




\section{Extraction Method: Principal Component Analysis}

Table7. Rotated component matrix

\begin{tabular}{|c|c|c|c|c|c|}
\hline & & & Component & & \\
\hline & 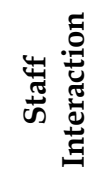 & 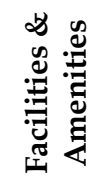 & 总 & 吾 & 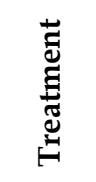 \\
\hline $\begin{array}{l}\text { Nurses interaction } \\
\text { Technician interaction } \\
\text { Doctor's interaction } \\
\text { Food } \\
\text { Accommodation } \\
\text { Formalities } \\
\text { Overall experience } \\
\text { Other } \\
\text { Arrival Procedure } \\
\text { Pre-visit procedures } \\
\text { Visa } \\
\text { Excursion } \\
\text { Ambience } \\
\text { Website information } \\
\text { Medical care } \\
\text { Cure } \\
\text { Variance } \\
\text { Cumulative variance } \\
\text { Cronbach's Alpha }\end{array}$ & $\begin{array}{l}.957 \\
.956 \\
.953\end{array}$ & $\begin{array}{l}.890 \\
.892 \\
.737 \\
.684 \\
.598\end{array}$ & $\begin{array}{l}.908 \\
.877 \\
.876\end{array}$ & $\begin{array}{l}.887 \\
.834 \\
.667 \\
\\
\\
10.588 \\
74.100 \\
.688\end{array}$ & $\begin{array}{l}.983 \\
.974 \\
\\
9.236 \\
83.336 \\
.975\end{array}$ \\
\hline
\end{tabular}

\section{Rotation Method: Varimax with Kaiser Normalization,} a. Rotation Converged in 14 Iterations

The perception of the tourists are analyzed through factor analysis whereby the 16 variables are categorized into five factors namely staff interaction, facilities and amenities, frontier formalities, tourism activities and treatment. Table-7 depicts the output with respect to factor loadings, Eigen values, variance, and Cronbach's Alpha. The first factor staff interaction comprises of three variables nurses interaction, technician interaction and doctor's interaction 
having factor loadings of .957, .956 and .953. The second factor facilities and amenities comprises of five factors food, accommodation, formalities, overall experience and other factors loadings of $.890, .892, .737, .684$ and .598 respectively. The third factor frontier formalities comprises of three variables including arrival procedure, pre-visit procedures, and Visa having factor loadings of $.908, .877$, and .876 respectively. The fourth factor comprises of three variables excursion, ambience, and website information having factor loadings of .887, .834, and .667 respectively. The last factor treatment comprises of variable medical care, and Cure having factor loadings of .983 and .974 . The variances of these factors are 34.326, 15.563, 13.624, 10.588 and 9.236 respectively. The Cumulative variances of these factors are 34.326, 49.888, 63.512, 74.100 and 83.336 respectively. Cronbach's Alpha for the five factors is $.979, .867, .922, .688$ and .975 respectively showing a greater internal consistency among the variables in each group. The explained variance among these variables was found to be $74.1 \%$.

Table 8. Descriptive Statistics

\begin{tabular}{|l|l|l|l|l|l|}
\hline Factor & Age & $\mathbf{N}$ & Mean & $\begin{array}{l}\text { Standard } \\
\text { Deviation }\end{array}$ & Std. Error \\
\hline \hline Staff & $25-40$ & 67 & 12.5373 & 1.70852 & .20873 \\
interaction & $41-55$ & 15 & 13.2667 & 1.86956 & .48272 \\
& $66-70$ & 8 & 14.6250 & 1.06066 & .37500 \\
Facilities and & Total & $\mathbf{9 0}$ & $\mathbf{1 2 . 8 4 4 4}$ & $\mathbf{1 . 7 8 5 7 8}$ &. $\mathbf{1 8 8 2 4}$ \\
Amenities & $25-40$ & 67 & 18.9552 & 2.23222 & .27271 \\
& $41-55$ & 15 & 19.8000 & 2.70449 & .69830 \\
& $66-70$ & 8 & 21.1250 & 2.03101 & .71807 \\
Frontier & Total & $\mathbf{9 0}$ & $\mathbf{1 9 . 2 8 8 9}$ & $\mathbf{2 . 3 6 6 6 4}$ &. $\mathbf{2 4 9 4 7}$ \\
Formalities & $25-40$ & 67 & 9.7612 & 1.46773 & .17931 \\
& $41-55$ & 15 & 11.0667 & 2.60403 & .67236 \\
& $66-70$ & 8 & 12.2500 & 1.58114 & .55902 \\
Tourism & Total & $\mathbf{9 0}$ & $\mathbf{1 0 . 2 0 0 0}$ & $\mathbf{1 . 8 7 3 5 3}$ & $\mathbf{. 1 9 7 4 9}$ \\
activities & $25-40$ & 67 & 9.5970 & 1.12895 & .13792 \\
& $41-55$ & 15 & 9.4667 & 1.24595 & .32170 \\
& $66-70$ & 8 & 9.2500 & .46291 & .16366 \\
Treatment & Total & $\mathbf{9 0}$ & $\mathbf{9 . 5 4 4 4}$ & $\mathbf{1 . 1 0 3 2 2}$ & $\mathbf{. 1 1 6 2 9}$ \\
& $25-40$ & 67 & 8.6716 & 1.10629 & .13516 \\
& $41-55$ & 15 & 8.6667 & 1.44749 & .37374 \\
& $66-70$ & 8 & 9.2500 & 1.03510 & .36596 \\
& Total & $\mathbf{9 0}$ & $\mathbf{8 . 7 2 2 2}$ & $\mathbf{1 . 1 6 1 4 4}$ & $\mathbf{1 2 2 4 3}$ \\
\hline
\end{tabular}

Table- 8 describes about the mean value and standard deviation to find out the differences among the different age groups on the satisfaction level of the four factors staff interaction, facilities and 
amenities, frontier formalities, tourism activities and treatment. The first part of the table reveals that the mean value ranges from 8.667 and 21.120 showing that there is a difference among the mean value. Taking into account the standard deviation from the mean value, it ranges from 2.70449 to .46291 . It infers that there exists some differences among the different age groups based on the five factors. To test for the significance in deviations, the One Way ANOVA test is conducted for the difference in satisfaction level.

\section{Table 9. ANOVA}

$\mathbf{H}_{0}$ : There is no significant difference in terms of age with a level of satisfaction among the five factors.

\begin{tabular}{|c|c|c|c|c|c|c|}
\hline & & $\begin{array}{l}\text { Sum of } \\
\text { Squares }\end{array}$ & df & $\begin{array}{l}\text { Mean } \\
\text { square }\end{array}$ & $\mathbf{F}$ & Sig \\
\hline $\begin{array}{l}\text { Staff } \\
\text { interactions }\end{array}$ & $\begin{array}{l}\text { Between Groups } \\
\text { Within Groups } \\
\text { Total }\end{array}$ & $\begin{array}{l}34.357 \\
249.465 \\
\mathbf{2 8 3 . 8 2 2}\end{array}$ & $\begin{array}{l}2 \\
87 \\
89\end{array}$ & $\begin{array}{l}17.179 \\
2.867\end{array}$ & 5.991 & .004 \\
\hline $\begin{array}{l}\text { Facilities and } \\
\text { Amenities }\end{array}$ & $\begin{array}{l}\text { Between Groups } \\
\text { Within Groups } \\
\text { Total }\end{array}$ & $\begin{array}{l}38.348 \\
460.141 \\
\mathbf{4 9 8 . 4 8 9}\end{array}$ & $\begin{array}{l}2 \\
87 \\
89\end{array}$ & $\begin{array}{l}19.174 \\
5.289\end{array}$ & 3.625 & .031 \\
\hline $\begin{array}{l}\text { Frontiers } \\
\text { formalities }\end{array}$ & $\begin{array}{l}\text { Between Groups } \\
\text { Within Groups } \\
\text { Total }\end{array}$ & $\begin{array}{l}57.788 \\
254.612 \\
\mathbf{3 1 2 . 4 0 0}\end{array}$ & $\begin{array}{l}2 \\
87 \\
89\end{array}$ & $\begin{array}{l}28.894 \\
2.927\end{array}$ & 9.873 & .000 \\
\hline $\begin{array}{l}\text { Tourism } \\
\text { activities }\end{array}$ & $\begin{array}{l}\text { Between Groups } \\
\text { Within Groups } \\
\text { Total }\end{array}$ & $\begin{array}{l}.969 \\
107.353 \\
\mathbf{1 0 8 . 3 2 2}\end{array}$ & $\begin{array}{l}2 \\
87 \\
89\end{array}$ & $\begin{array}{l}.485 \\
1.234\end{array}$ & .393 & .676 \\
\hline Heder & $\begin{array}{l}\text { Between Groups } \\
\text { Within Groups } \\
\text { Total }\end{array}$ & $\begin{array}{l}2.446 \\
117.609 \\
\mathbf{1 2 0 . 0 5 6} \\
\end{array}$ & $\begin{array}{l}2 \\
87 \\
89 \\
\end{array}$ & $\begin{array}{l}1.223 \\
1.352\end{array}$ & .905 & .408 \\
\hline
\end{tabular}

From the above Table-9, the first three factors show significant difference among the different age groups. Thus null hypothesis is supported by the first three factors. But the fourth and fifth factors show insignificant difference. This does not support the null hypothesis. 


\section{Table 10. Descriptive statistics}

$\mathbf{H}_{0}$ : There is no significant difference in terms of gender with the level of satisfaction among the five factors.

\begin{tabular}{|l|l|l|l|l|l|}
\hline & Gender & $\mathbf{N}$ & Mean & $\begin{array}{l}\text { Std. } \\
\text { Deviation }\end{array}$ & $\begin{array}{l}\text { Std. } \\
\text { Error } \\
\text { Mean }\end{array}$ \\
\hline \hline Staff interactions & Male & 62 & 12.6935 & 1.75171 & .22247 \\
& Female & 28 & 13.1786 & 1.84699 & .34905 \\
Facilities and & Male & 62 & 19.4516 & 2.11689 & .26885 \\
Amenities & Female & 28 & 18.9286 & 2.85357 & .53927 \\
Frontiers & Male & 62 & 10.1935 & 1.95724 & .24827 \\
formalities & Female & 28 & 10.2143 & 1.70744 & .32268 \\
Tourism activities & Male & 62 & 9.5161 & 1.08253 & .13748 \\
& Female & 28 & 9.6071 & 1.16553 & .22026 \\
Treatment & Male & 62 & 8.7903 & 1.04233 & .13238 \\
& Female & 28 & 8.5714 & 1.39917 & .26442 \\
\hline
\end{tabular}

Table-10 describes about the mean value and standard deviation to find out the differences among the two gender groups on the satisfaction level of the five factors staff interaction, facilities and amenities, frontier formalities, tourism activities and treatment. The first part of the table reveals that the mean value ranges from 8.5714 and 19.4516 showing that there is difference among the mean value. Taking into account the standard deviation from the mean value, it ranges from 1.04233 to 2.85357 . It infers that there exist some differences among the different gender groups based on the five factors. To compare the mean scores between the two gender groups the equality of variances is identified through Levene's T test as shown in Table- 11. 
Table 11. Levene's T-Test

\begin{tabular}{|c|c|c|c|c|c|c|c|c|}
\hline & & \multicolumn{3}{|c|}{$\begin{array}{c}\text { Levene's Test for Equality } \\
\text { of Variances }\end{array}$} & \multicolumn{4}{|c|}{ t-test for Equality of Means } \\
\hline & & 5 & 离 & H & $\check{a}$ & 总 & 徰 & 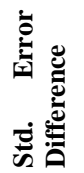 \\
\hline & & & & & & & & \\
\hline Fac 1 & $\begin{array}{l}\text { Equal variances } \\
\text { assumed } \\
\text { Equal variances } \\
\text { not assumed }\end{array}$ & 7.753 & .388 & $\begin{array}{l}-1.196 \\
-1.172\end{array}$ & $\begin{array}{l}88 \\
49.757\end{array}$ & $\begin{array}{l}.235 \\
.247\end{array}$ & $\begin{array}{l}-.48502 \\
-.48502\end{array}$ & $\begin{array}{l}.40563 \\
.41392\end{array}$ \\
\hline Fac 2 & $\begin{array}{l}\text { Equal variances } \\
\text { assumed } \\
\text { Equal variances } \\
\text { not assumed }\end{array}$ & 5.658 & .020 & $\begin{array}{l}.970 \\
.868\end{array}$ & $\begin{array}{l}88 \\
40.969\end{array}$ & $\begin{array}{l}.335 \\
.390\end{array}$ & $\begin{array}{l}.52304 \\
.52304\end{array}$ & $\begin{array}{r}.53904 \\
.60257\end{array}$ \\
\hline Fac3 & $\begin{array}{l}\text { Equal variances } \\
\text { assumed } \\
\text { Equal variances } \\
\text { not assumed }\end{array}$ & .148 & .701 & $\begin{array}{l}-.048 \\
-.051\end{array}$ & $\begin{array}{l}88 \\
59.308\end{array}$ & $\begin{array}{l}.962 \\
.960\end{array}$ & $\begin{array}{l}-.02074 \\
-.02074\end{array}$ & $\begin{array}{r}.42900 \\
.40732\end{array}$ \\
\hline Fac4 & $\begin{array}{l}\text { Equal variances } \\
\text { assumed } \\
\text { Equal variances } \\
\text { not assumed }\end{array}$ & .067 & .797 & $\begin{array}{l}-.361 \\
-.351\end{array}$ & $\begin{array}{l}88 \\
48.853\end{array}$ & $\begin{array}{l}.719 \\
.727\end{array}$ & $\begin{array}{l}-.09101 \\
-.09101\end{array}$ & $\begin{array}{l}.25243 \\
.25965\end{array}$ \\
\hline Fac5 & $\begin{array}{l}\text { Equal variances } \\
\text { assumed } \\
\text { Equal variances } \\
\text { not assumed }\end{array}$ & 3.428 & .067 & $\begin{array}{l}.826 \\
.740\end{array}$ & $\begin{array}{l}88 \\
41.088\end{array}$ & $\begin{array}{l}.411 \\
.463\end{array}$ & $\begin{array}{l}.21889 \\
.21889\end{array}$ & $\begin{array}{l}.26492 \\
.29570\end{array}$ \\
\hline
\end{tabular}

It is found that the variances are approximately equal. It is found from the table that the two-tailed significance is more than 0.05 and hence the hypothesis is supported. There is no significant difference between the genders about the level of satisfaction among the five factors.

\section{Findings}

The study has found that Medical tourism in most of the hospitals has been identified as one of the critical factors. Majority of the hospitals do marketing overseas through word of mouth and the MOU with government especially the trust hospitals, perhaps corporate hospitals are also concentrating on hospital tie-ups, advertisements, newspaper articles, travel agency websites, representative office and agents in other country. The facilities 
provided to foreign patients are customer oriented, depending upon the requirement and budget of the patient. Quality and low cost treatment is the major motivating factor for an international patient to visit India. Most of the foreign patients came to know about the hospital and contacted through relatives and friends. Thus, word of mouth plays a major role in marketing the product of hospital. Most of the patients visiting Puducherry do it for holiday and cure which is a positive indication for Medical tourism in Puducherry. The reason for deciding India for treatment is that hospitals in India have better health care facility and are cheaper when compared to the other countries. It indicates that the hospitals have identified the critical factor, which attracts the international patients and are able to satisfy their demands. The satisfaction level of patients regarding the staff interaction, facilities and amenities and treatment is high. But, there is some need of improvement in the case of formalities and tourism part.

\section{Discussion}

Puducherry is found to have all the potentials pertaining to the tourist attractions and medical tourism attractions in particular. The important thing which is missing is the support from the government and the awareness among the tourists. Puducherry almost has around fifty hospitals out of which at least ten are multispecialty hospitals. The increase in the number of tourists through the years gives a solid thrust to concentrate on tourism as far as Puducherry is concerned. It is the lack of initiative from the government and the coordination between the stakeholders of the travel industry as well as the hospital industry that has to be given importance. The efficiency of the doctors, their personal touch, their communication skills, the facilities and amenities of the hospitals contributes to the cutting edge experience of the medical tourists. One important drawback is the lack of international accreditation which needs utmost ground work. 
Fig. 1. Strategies for medical tourism decision making in Puducherry

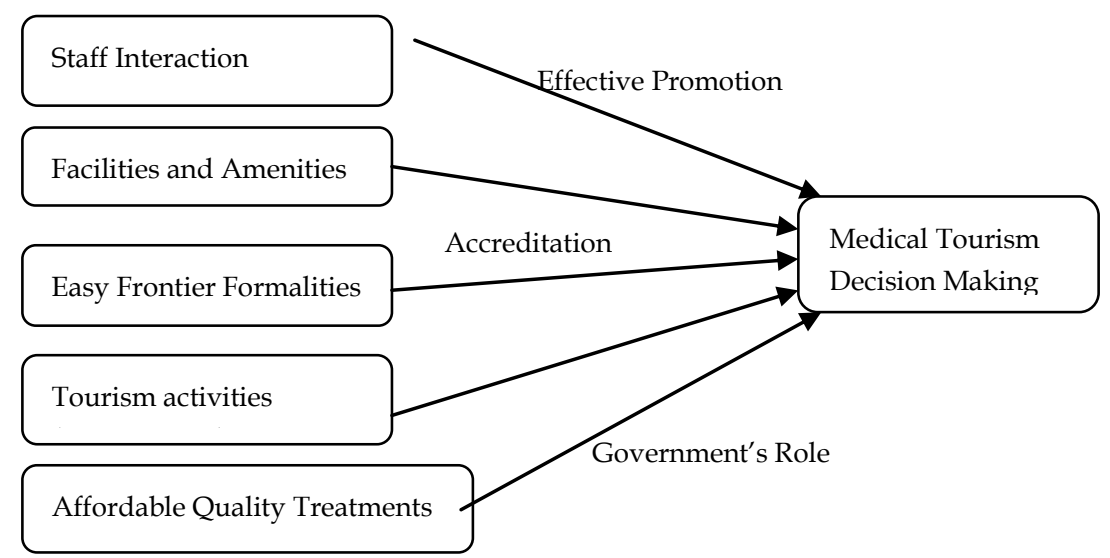

The above model explains the strategies that lead to medical tourism decision making. It is the proper mix of staff interaction, facilities and amenities, easy frontier formalities, recuperative activities through tourism and the affordable quality treatments that blended with effective promotional strategies, international accreditation and the high end role of the government that could lead to medical tourism decision-making to visit Puducherry.

\section{Conclusion}

The study thus concludes that Puducherry has a lot of potential which helps the medical tourists to decide where they have to travel. As per the perception of the medical tourists it is found that Puducherry has many specialty hospitals, prompt service, affordable price fitting into the budget of the tourist, and efficient treatments. The study helps to position Puducherry in the minds of the people to think of having a medical treatment clubbed with the tourist activities. The study further prompts to conduct future studies on the public private partnership in promoting Puducherry as a medical tourism destination. 


\section{References}

Bies, W., \& Zacharia, L. (2007). Medical tourism: Outsourcing surgery. Mathematical and Computer Modelling, 46, 1144-1159.

CBS News (2008, July 5). Medical tourism: Need surgery, will travel. Retrieved from http://www.medical-tourism-india.com/.

Korea Health Industry Development Institute. (2009). A Survey Report of medical environment in China. Seoul.

Outsourcing your heart: Elective surgery in India? Medical tourism is booming, and us companies trying to contain health-care costs are starting to take notice. (2006, May 21). Time Magazine.

RNCOS. (2008). Asian Medical Tourism Analysis. India.

Shedlock, M. (2010, October 24). Medical tourism from http:// globaleconomicanalysis.blogspot.com/.

Yu, J. Y., \& Ko, T. G. (2012). A cross-cultural study of perceptions of medical tourism among Chinese, Japanese and Korean tourists in Korea. Tourism Management, 33, 80-88. 